\title{
PENGARUH MOTIVASI DAN KEPUASAN KERJA TERHADAP KINERJA PEGAWAI BADAN PUSAT STATISTIK KABUPATEN OGAN ILIR
}

\author{
Tutik Pebrianti \\ Imam Suroso \\ Universitas Sjakhyakirti Palembang \\ Email : \\ Tutikpebrianti@unisti.ac.id \\ Imamsuroso@unisti.ac.id
}

\begin{abstract}
This study entitled " the effect of motivation and job satisfaction toward job performance of Badan Pusat Statistik employees Ogan Ilir regency". Population is used in this study is 31 persons employees of Badan Pusat Statistik Ogan Ilir regency and all of population is as sample, too by consideration that all the employees have more than two years working period and they have status as civil servants. Sampling technique used saturated sampling. Partially research result showed that motivation has no significantly effect towards employees job performance but in contrast job satisfaction has a partially significanteffect Towards empolyees job performance of Badan Pusat Statistik Ogan Ilir regency with $f$ obtained value is 10.295 andR square value is 0.433 (43.3\%) with multiple regression equation: $Y=6.619+0,256 X 1+0,3 X 2+e$. While dominant variable which is influence Badan Pusat Statistik employees' job performance in Ogan Ilir regency is job satisfaction variable by significant valUe $(p=0.05$ and $b=0.3)$. If the employees' job satisfaction is high so organization performance will be good and vice versa.
\end{abstract}

Keywords : Motivation,job satisfaction, and job performance.

\section{PENDAHULUAN}

\section{Latar Belakang Masalah}

Untuk mempengaruhi pegawai agar meningkatkan kinerja, suatu organisasi harus mengetahui dan memahami terlebih dahulu motif apa yang mendorong mereka untuk bekerja. Pada dasarnya keinginan untuk dapat memenuhi kebutuhan baik fisik maupun rohani adalah penggerak atau pendorong seseorang untuk bekerja keras yang biasanya disebut dengan motivasi. Seperti yang dikemukakan oleh Hasibuan (2000:142), dimana Motivasi adalah pemberian daya penggerak yang menciptakan kegairahan kerja seseorang, agar mereka mau bekerja efektif dan terintegrasi dengan segala daya upaya untuk mencapai kepuasan.

Pegawai yang termotivasi dan memiliki semangat kerja akan mendorong kearah kepuasan kerja. Sehingga dengan demikian diharapkan karyawan yang merasakan kepuasan kerja tersebut akan melakukan pekerjaan dengan baik dan meningkatkan kinerjanya. Menurut Hasibuan (2000:202), kepuasan kerja adalah sikap emosional yang menyenangkan dan 
mencintai pekerjaannya. Sikap ini dicerminkan oleh moral kerja, kedisiplinan dan prestasi kerja. Kepuasan kerja dinikmati dalam pekerjaan, luar pekerjaan dan kombinasi dalam dan luar pekerjaan.

Kepuasan kerja atau ketidakpuasan kerja pegawai tergantung pada perbedaan antara apa yang diharapkan dan apa yang didapat. Sebaliknya apabila yang di dapat pegawai lebih rendah dari pada yang diharapkan akan menyebabkan pegawai tidak puas. Baik atau tidaknya kinerja dari setiap pegawai merupakan hal yang penting bagi organisasi pemerintah, karena dengan memiliki pegawai yang mempunyai kinerja yang baik maka kinerja instansi pemerintah secara keseluruhan juga akan baik. Defenisi Kinerja menurut Mangkunegara (2000:67) adalah hasil kerja secara kualitas yang dan kuantitas yang dicapai oleh seorang pegawai dalam melaksanakan tugasnya sesuai dengan tanggung jawab yang diberikan kepadanya. Dengan terciptanya kinerja yang baik maka tujuan organisasi akan dapat tercapai sesuai dengan apa yang diharapkan.

Dengan adanya motivasi yang tinggi dan kepuasan kerja yang baik tercermin dari rasa tanggung jawab dan gairah kerja yang menciptakan suatu keinginan untuk bekerja dan memberikan sesuatu yang terbaik untuk pekerjaannya. Pentingnya motivasi dan kepuasan kerja menuntut seorang pemimpin untuk peka terhadap kepentingan pegawai sehingga kinerja instansi dapat terus ditingkatkan.

Demikian pula halnya dengan kantor Badan Pusat Statistik Kabupaten Ogan Ilir yang merupakan lembaga pemerintahan non kementrian yang tidak terlepas dari tujuannya untuk meningkatkan kualitas data, pelayanan prima dan meningkatkan sumber daya manusia yang professional berintegritas serta amanah. Untuk mencapai tujuan tersebut pegawai menjadi salah satu faktor yang paling penting harus diperhatikan dengan pemberian motivasi dalam bentuk materil seperti halnya gaji maupun tunjagan lainnya. Seperti halnya pegawai Badan Pusat Statistik Kabupaten Ogan Ilir juga membutuhkan pemenuhan kebutuhan akan prestasi, afiliasi dan kebutuhan akan kekuasaan untuk dapat memotivasi mereka bekerja lebih baik. Demikian pula dengan kepuasan kerja yang diharapkan oleh pegawai tidak hanya menginginkan besarnya gaji yang diberikan tetapi juga tantangan dari pekerjaan itu sendiri, adanya kesempatan untuk mendapatkan promosi, dukungan serta terjalinnya hubungan kerja yang baik dengan sesama pegawai.

Oleh Karena itu, instansi pemerintahan harus dapat memahami apa yang menjadi kebutuhan serta keinginan pegawai sehingga pegawai tersebut merasakan kepuasan dalam bekerja dan mempunyai motivasi yang tinggi sehingga pegawai tersebut dapat bekerja dengan lebih baik dan kinerja organisasi pemerintahan juga dapat terus dipertahankan bahkan ditingkatkan. Berdasarkan uraian diatas, peneliti tertarik untuk melakukan penelitian dengan judul yaitu "Pengaruh Motivasi Dan Kepuasan Kerja Terhadap Kinerja Pegawai Badan Pusat Statistik Kabupaten Ogan Ilir”

\section{Rumusan Masalah}

1. Bagaimana motivasi berpengaruh secara parsial terhadap kinerja Pegawai Badan Pusat Statistik Kabupaten Ogan Ilir.

2. Bagaimana kepuasan kerja berpengaruh secara parsial terhadap kinerja Pegawai Badan Pusat Statistik Kabupaten Ogan Ilir.

3. Bagaimana motivasi dan kepuasan kerja berpengaruh secara simultan terhadap kinerja Pegawai Badan Pusat Statistik Kabupaten Ogan Ilir.

4. Variabel mana yang paling berpengaruh terhadap .kinerja pegawai Kantor Badan Pusat Statistik Kabupaten ogan Ilir.

\section{Tujuan Penelitian}


1. Motivasi berpengaruh secara parsial terhadap kinerja Pegawai Badan Pusat Statistik Kabupaten Ogan Ilir.

2. Kepuasan kerja berpengaruh secara parsial terhadap kinerja Pegawai Badan Pusat Statistik Kabupaten Ogan Ilir.

3. Motivasi dan kepuasan kerja berpengaruh secara simultan terhadap kinerja Pegawai Badan Pusat Statistik Kabupaten Ogan Ilir.

4. Variabel yang paling berpengaruh terhadap kinerja pegawai Kantor Badan Pusat Statistik Kabupaten ogan Ilir.

\section{KAJIAN PUSTAKA}

Kinerja

Konsep tentang kinerja diungkapkan oleh Mangkunegara (2000: 67) mendefinisikan Kinerja (prestasi kerja) adalah hasil kerja secara kualitas dan kuantitas yang dicapai oleh seseorang pegawai dalam melaksanakan tugasnya sesuai dengan tanggung jawab yang diberikan kepadanya. Sedangkan kinerja menurut RivaiVeithzal (2004: 309) adalah perilaku yang nyata yang ditampilkan setiap orang sebagai prestasi kerja yang dihasilkan oleh karyawan sesuai dengan perannya dalam perusahaan.

Hasibuan (2001:34) juga menjelaskan bahwa kinerja merupakan hasil kerja yang dicapai seseorang dalam melaksanakan tugas-tugas yang dibebankan kepadanya didasarkan atas kecakapan, pengalaman, kesungguhan dan waktu. Lebih lanjut, Hasibuan mengungkapkan bahwa kinerja merupakan gabungan tiga faktor penting, yaitu kemampuan dan minat seorang pekerja, kemampuan dan penerimaan atas penjelasan delegasi tugas dan peran serta tingkat motivasi pekerja. Apabila kinerja tiap individu atau karyawan baik, maka diharapkan kinerja perusahaan akan baik pula. Jadi dapat disimpulkan bahwa kinerja merupakan hasil yang dicapai seseorang baik secara kualitas maupun kuantitas dalam melaksanakan pekerjaannya menurut ukuran yang berlaku untuk pekerjaan yang bersangkutan.

\section{Kepuasan Kerja}

Salah satu sarana penting pada manjemen sumber daya manusia dalam sebuah orgaisasi adalah terciptanya kepuasan kerja para pegawai/ karyawan. Kepuasan kerja menurut Robbins (2001: 139), merupakan sikap umum seorang individu terhadap pekerjaannya. Seseorang dengan tingkat kepuasan kerja tinggi menunjukkan sikap yang positif terhadap pekerjaannya dan seseorang yang tidak puas dengan pekerjaannya menunjukkan sikap yang negatif terhadap pekerjaan itu. Sikap individu, baik itu positif maupun negatif akan tampak pada tiga indikasi output / hasil kerjanya yaitu tingkat absensi, turn-over (keluar dan masuknya karyawan) dan produktivitas kerja.

Menurut Malthis dan Jackson (2006: 121), Kepuasan kerja adalah keadaan emosional yang positif yang merupakan hasil dari evaluasi pengalaman kerja seseorang. Seseorang akan merasakan kepuasan dalam bekerja ketika apa yang diharapkan dari pekerjaannya dan apa yang diterimanya sebagai penghargaan dari pekerjaannya dapat tepenuhi. Sebaliknya ketidakpuasan kerja akan muncul ketika harapan seseorang tidak terpenuhi. Malayu S.P. Hasibuan (2006:202) menambahkan bahwa kepuasan kerja adalah sikap emosional yang menyenangkan dan mencintai pekerjaannya. Sikap ini dicerminkan oleh moral kerja, kedisiplinan, dan prestasi kerja. Kepuasan kerja dinikmati dalam pekerjaan, luar pekerjaan, dan kombinasi antara keduanya.

Menurut Luthans dan Spector dalam Robins (2001:149), ada lima faktor penentu kepuasan yaitu

1. Pekerjaan itu sendiri. 
Tingkat dimana sebuah pekerjaan menyediakan tugas yang menyenangkan, kesempatan belajar dan kesempatan untuk mendapatkan tanggung jawab. Hal ini menjadi sumber mayoritas kepuasan kerja. Menurut Locke, ciri-ciri intrinsik yang menentukan kepuasan kerja adalah keragaman, kesulitan, jumlah pekerjaan, tanggung jawab, otonomi, kendali terhadap metode kerja, kemajemukan, dan kreativitas.

2. Gaji

Menurut penelitian Theriault, kepuasan kerja merupakan fungsi dari jumlah absolute dari gaji yang diterima, derajad sejauh mana gaji memenuhi harapanharapan tenaga kerja, dan bagaimana gaji diberikan. Upah dan gaji diakui merupakan faktor yang signifikan terhadap kepuasan kerja.

3. Kesempatan atau promosi

Karyawan memiliki kesempatan untuk mengembangkan diri dan memperluas pengalaman kerja, dengan terbukanya kesempatan untuk kenaikan jabatan.

4. Supervisor

Kemampuan supervisor untuk menyediakan bantuan teknis dan perilakudukungan. Menurut Locke, hubungan fungsional dan hubungan keseluruhan yang positif memberikan tingkat kepuasan kerja yang paling besar dengan atasan

5. Rekan kerja

Kebutuhan dasar manusia untuk melakukan hubungan sosial akan terpenuhi dengan adanya rekan kerja yang mendukung karyawan. Jika terjadi konflik dengan rekan kerja, maka akan berpengaruh pada tingkat kepuasan karyawan terhadap pekerjaan.

Jadi dapat disimpulkan bahwa kepuasan kerja merupakan sikap emosional yang dirasakan dan bersifat individual dimana setiap individu akan memiliki tingkat kepuasan yang berbeda-beda sesuai dengan perbedaan antara apa yang dirasakan dengan apa yang diharapkan. Ini disebabkan karena adanya perbedaan pada masing-masing individu. Semakin banyak aspek-aspek dalam pekerjaan yang sesuai dengan keinginan individu, maka akan semakin tinggi tingkat kepuasan yang dirasakan, begitu pula sebaliknya.

\section{Motivasi}

Menurut Malthis \& Jakson (2006:114), Motivasi adalah keinginan dari dalam diri seseorang yang menyebabkan orang tersebut bertindak. Orang biasanya akan bertindak karena suatu alasan untuk mencapai tujuan tertentu. Sementara menurut Fred Luthans (2011:422) motivasi adalah proses sebagai langkah awal seseorang melakukan tindakan akibat kekurangan secara fisik dan psikis atau dengan kata lain adalah suatu dorongan yang ditujukan untuk memenuhi tujuan tertentu.

\section{Teori Motivasi Maslow}

Setiap manusia mempunyai needs (kebutuhan, dorongan, intrinsic dan extrinsic factor), yang pemunculannya sangat tergantung dari kepentingan individu. Dengan ke nyataan ini, kemudian A. Maslow membuat "needs hierarchy theory" untuk menjawab tentang tingkatan kebutuhan manusia tersebut. Hierarki Kebutuhan manusia menurut Abraham Maslow dalam Hasibuan (2007: 105-107) diklasifikasikan menjadi lima hierarki kebutuhan yaitu:

1) Kebutuhan Fisiologis ( Physiological Needs )

Perwujudan dari kebutuhan fisiologis adalah kebutuhan pokok manusia yaitu sandang, pangan, papan, dan kesejahteraan individu. Kebutuhan ini dipandang sebagai kebutuhan yang paling mendasar, karena tanpa pemenuhan kebutuhan tersebut, seseorang tidak dapat dikatakan hidup normal. Meningkatnya kemampuan seseorang cenderung mereka berusaha meningkatkan pemuas kebutuhan dengan pergeseran dari kuntitatif ke kualitatif. 
Kebutuhan ini merupakan kebutuhan yang amat primer, karena kebutuhan ini telah ada dan terasa sejak manusia dilahirkan.

2) Kebutuhan keamanan dan keselamatan (Safety and security Need).

Kebutuhan keamanan dan keselamatan adalah kebutuhan akan keamanan dari ancaman yakni merasa aman dari ancaman kecelakaan dan keselamatan dalam melakukan pekerjaan. Kebutuhan ini mengarah kepada sua bentuk, yaitu:

a. Kebutuhan akan keamanan dan keselamatan jiwa di tempat pekerjaan pada saat mengerjakan pekerjaan di waktu jam-jam kerja. Para pekerja membutuhkan alat pelindung seperti masker bagi tukang las yang diberikan oleh manajer. Dalam arti luas, setiap orang membutuhkan keamanan dan keselamatan jiwanya dimanapun ia berada.

b. Kebutuhan akan keamanan harta di tempat pekerjaan pada waktu jam jam jam kerja, misalnya motor yang disimpan jangan sampai hilang. Pentingnya memuaskan kebutuhan ini jelas terlihat pada organisasi modern, tempat pimpinan organisasi mengutamakan keamanan dan keselamatan dengan mempergunakan alat-alat canggih atau pengawalan. Bentuk lain dari pemuasan kebutuhan ini dengan memberikan perlindungan asurasi kepada para karyawan.

3) Kebutuhan Sosial (Affiliation Needs).

Affiliation Needs merupakan kebutuhan sosial, teman, dicintai dan mencintai serta diterima dalam pergaulan kelompok karyawan dan lingkungannya. Manusia pada dasarnya selalu ingin hidup berkelompok dan tidak seorang pun manusia ingin hidup menyendiri di tempat terpencil. Karena manusia adalah makhluk sosial, sudah jelas ia menginginkan kebutuhan-kebutuhan social yang terdiri dari empat kelompok, yaitu:

a. Kebutuhan akan perasaan diterima oleh orang lain di lingkunganhidup dan bekerja (sense of belonging).

b. Kebutuhan akan perasaan dihormati, karena setiap manusia merasa dirinya penting (sense of importance). Serendah-rendahnya pendidikan dan kedudukan seseorang ia tetap merasa dirinya penting. Karena itu dalam memotivasi bawahan pimpinan harus dapat melakukan tindakan yang menimbulkan kesan bahwa tenaga mereka diperlukan dalam proses pencapaian tujuan perusahaan.

c. Kebutuhan akan perasaan kemajuan dan tidak seorang pun yang menyenangi kegagalan. Kemajuan di segala bidang merupakan keinginan dan kebutuhan yang menjadi idaman setiap orang.

d. Kebutuhan akan perasaan ikut serta (sense of participation).

Setiap karyawan akan merasa senang, jika diikutsertakan dalam mengemukakan saransaran, pendapat-pendapatnya kepada pimpinan mereka.

4) Kebutuhan akan harga diri (Esteem Needs).

orang memerlukan pengakuan atas keberadaan statusnya oleh orang lain. Situasi yang ideal adalah apabila prestise itu timbul akan menjadikan prestasi seseorang. Akan tetapi tidak selalu demikian, karena dalam hal ini semakin tinggi kedudukan seseorang, maka akan semakin banyak hal yang digunakan sebagai simbol statusnya itu. Dalam kehidupan organisasi banyak fasilitas yang diperoleh seseorang dari organisasi untuk menunjukkan kedudukan statusnya dalam organisasi. Pengalaman menunjukkan bahwa baik dimasyarakat yang masih tradisional maupun dilingkungan masyarakat yang sudah maju, simbol - simbol status tersebut tetap mempunyai makna penting dalam kehidupan berorganisasi.

5) Kebutuhan aktualisasi diri (Self Actualization Needs).

Aktualisasi diri adalah kebutuhan akan aktualisasi diri dengan menggunakan kecakapan, kemampuan, keterampilan, dan potensi optimal untuk mencapai prestasi kerja yang sangat 
memuaskan atau luar biasa yang sulit dicapai orang lain. Kebutuhan ini merupakan merupak realisasi lengkap potensi seseorang secara penuh. Keinginan seseorang untuk mencapai kebutuhan sepenuhnya dapat berbeda satu dengan lainnya. Pemenuhan ini dapat dilakukan oleh para pimpinan perusahaan dengan menyelenggarakan pendidikan dan pelatihan.

\section{Faktor-Faktor yang Mempengaruhi Motivasi}

Memberikan motivasi kepada pegawai oleh pimpinannya merupakan proses kegiatan pemberian motivasi kerja, sehingga pegawai tersebut berkemampuan untuk pelaksanaan pekerjaan dengan penuh tanggung jawab. Tanggung jawab adalah kewajiban bawahan untuk melaksanakan tugas sebaik mungkin yang diberikan oleh atasan, dan inti dari tanggung jawab adalah kewajiban. Nampaknya pemberian motivasi oleh pimpinan kepada bawahan tidaklah begitu sukar, namun dalam praktiknya pemberian motivasi jauh lebih rumit. Siagian (2001:287) menjelaskan kerumitan ini disebabkan oleh:

1. Kebutuhan yang tidak sama pada setiap pegawai, dan berubah sepanjang waktu. Disamping itu perbedaan kebutuhan pada setiap taraf sangat mempersulit tindakan motivasi para manajer. Dimana sebagian besar para manajer yang ambisius, dan sangat termotivasi untuk memperoleh kepuasan dan status, sangat sukar untuk memahami bahwa tidak semua pegawai mempunyai kemampuan dan semangat seperti yang dia miliki, sehingga manajer tersebut menerapkan teori coba-coba untuk menggerakkan bawahannya.

2. Feeling dan emotions yaitu perasaan dan emosi.

Seseorang manajer tidak memahami sikap dan kelakuan pegawainya, sehingga tidak ada pengertian terhadap tabiat dari perasaan, keharusan, dan emosi.

3. Aspek yang terdapat dalam diri pribadi pegawai itu sendiri seperti kepribadian, sikap, pengalaman, budaya, minat, harapan, keinginan, lingkungan yang turut mempengaruhi pribadi pegawai tersebut.

4. Pemuasan kebutuhan yang tidak seimbang antara tanggung jawab dan wewenang. Wewenang bersumber atau datang dari atasan kepada bawahan, sebagai imbalannya pegawai bertanggung jawab kepada atasan, atas tugas yang diterima. Seseorang dengan kebutuhan akan rasa aman yang kuat mungkin akan "mencari amannya saja", sehingga akan menghindar menerima tanggung jawab karena takut tidak berhasil dan diberhentikan dan di lain pihak mungkin seseorang akan menerima tanggung jawab karena takut diberhentikan karena alasan prestasi kerja yang jelek (buruk).

\section{METODOLOGI PENELITIAN}

Populasi adalah sekumpulan kasus yang perlu memenuhi syarat-syarat yang berkaitan dengan masalah penelitian (Arikunto, 1998:115). Sedangkan sampel adalah sebagian atau wakil dari populasi yang diteliti (Arikunto, 1998:109). Karena jumlah populasi yang terbatas yaitu sebanyak 31 orang, maka dalam penelitian ini semua anggota populasi dijadikan sampel penelitian atau sampel total. Jadi dalam penelitian ini sampel yang digunakan sebanyak 31 responden.

Maka teknik sampling yang peneliti gunakan dalam penelitian ini adalah sampling jenuh yaitu teknik penentuan sampel bila semua anggota populasi digunakan sebagai sampel (Sugiyono, 2011: 68). Sampel yang dijadikan responden dalam penelitian ini adalah pegawai Badan Pusat Statistik Kabupaten Ogan Ilir dengan pertimbangan bahwa pegawai memiliki lama masa kerja jauh lebih dari dua tahun. Disamping itu pegawai adalah pegawai negeri 
sipil yang terkait dengan kegiatan pelayanan administrasi serta pegawai yang bertugas di lapangan.

Sumber data yang digunakan dalam penelitian ini yaitu data primer dan data sekunder. Data Primer menurut Umi Narimawati (2008: 98) data primer adalah sumber data yang langsung memberikan data kepada pengumpul data. Data primer disebut juga sebagai data asli atau data baru yang memiliki sifat up to date. Untuk mendapatkan data primer, peneliti mengumpulkannya secara langsung dari pegawai Badan Pusat Statistik Kabupaten Ogan Ilir melalui wawancara dan penyebaran kuisioner. Data Sekunder merupakan sumber yang tidak langsung memberikan data kepada pengumpul data, misalnya orang lain atau lewat dokumen Sugiono (2008: 402). Data sekunder ini peneliti peroleh dari Badan Pusat Statistik Kabupaten Ogan Ilir yang berupa struktur organisasi, profil organisasi dan data jumlah karyawan.

Teknik pengumpulan data yang digunakan dalam penelitian ini adalah Riset lapangan, dimana pengumpulan data dilakukan di tempat yang menjadi objek yang akan diteliti dengan mengunjungi langsung objek tersebut, dalam hal ini Kantor Badan Pusat Statistik Kabupaten Ogan Ilir.

1. Wawancara, merupakan teknik pengumpulan data yang digunakan peneliti untuk mendapatkan keterangan-keterangan lisan melalui bercakap-cakap dan berhadapan muka dengan orang yang dapat memberikan keterangan kepada peneliti. Dalam hal ini peneliti malakukan wawancara dengan pegawai Badan Pusat Statistik Kabuapten Ogan Ilir terkait dengan permasalahan dalam penelitian ini

2. Kuisioner, adalah teknikpengumpulan data melalui formulir-formulir yang berisi pertanyaan-pertanyaan yang diajukan secara tertulis pada seseorang atau sekumpulan orang untuk mendapatkan jawaban atau tanggapan dan informasi yang diperlukan oleh peneliti Mardalis (2008: 66). Dalam hal ini peneliti menyebarkan kuisioner kepada Pegawai Badan Pusat Statistik Kabupaten Ogan Ilir dengan materi pertanyaan yang berhubungan dengan motivasi, kepuasan kerja dan kinerja karyawan.

3. Observasi, merupakan metode pengumpul data yang dilakukan dengan cara mengamati dan mencatat secara sistematik gejala-gejala yang diselidiki”, Supardi(2006: 88). Dalam hal ini peneliti melakukan pengamatan langsung terhadap aktivitas kerja Pegawai Badan Pusat Statistik Kabupaten Ogan Ilir. Riset Kepustakaan yaitu pengumpulan data dimana peneliti menyelidiki benda-benda tertulis seperti buku-buku, majalah, dokumen, peraturan-peraturan,dan sebagainya, Arikunto (2002: 158). Teknik ini juga mencakup buku- buku litelatur yang peneliti jadikan landasan teori dalam pembahasan selanjutnya yang berhubungan dengan penelitian yang sedang dilakukan.

Teknik analisis data yang digunakan dalam penelitian ini adalah dengan menggunakan teknik analisis kuantitatif deskriptif. Menurut Sugiyono (2003:21) Teknik analisis statistic deskriptif adalah statistik yang digunakan untuk menganalisa data dengan cara mendeskripsikan atau menggambarkan data yang telah terkumpul sebagaimana adanya tanpa bermaksud membuat kesimpulan yang berlaku untuk umum atau generalisasi.

Teknik analisis data dalam penelitian ini dilakukan dengan analysis regresi berganda. Anatisis regresi dilakukan untuk melihat pengaruh variabel bebas terhadap variabel terikat untuk menjawab rumusan masalah yang telah diungkapkan di bagian awal. Untuk rnenguji hipotesis pertama dan kedua dilakukan dengan statistik uji-t (pengujian secara parsial) sedangkan hipotesis ketiga diuji dengan statistik uji-F.

Model umum persamaan regresi dalam penelitian ini adalah sebagai berikut:

$\mathrm{Y}=\mathrm{a}+\mathrm{bX} 1+\mathrm{bX} 2+\mathrm{e}$

Ket:

$\mathrm{Y}=$ Kinerja Karyawan

Desember 2018

JURNAL MANAJEMEN KOMPETEN 


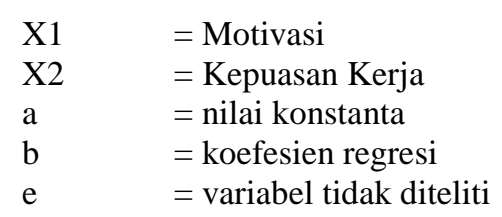

\section{HASIL DAN PEMBAHASAN Hasil Uji Validitas}

Uji validitas digunakan untuk mengukur sah atau valid tidaknya suatu kuisioner. Dalam hal ini uji validitas dilakukan dengan jumlah sampel sebanyak 30 responden. Suatu kuisioner dikatakan valid jika pertanyaan pada kuisioner dapat mengungkapkan sesuatu yang akan diukur oleh kuisioner tersebut. Uji signifikansi dilakukan dengan membandingkan nilai $\mathrm{r}$ hitung dengan nilai $\mathrm{r}$ table untuk degree of freedom $(\mathrm{df})=\mathrm{n}-\mathrm{k}$, dalam hal ini $\mathrm{n}$ adalah jumlah sampel dan k adalah jumlah konstruk. Pada penelitian ini besarnya df dihitung dengan $30-2$ atau df 28 dengan alpha 0.05 didapat $r$ table 0.361. Jika $r$ hitung (untuk $r$ tiap butir data dilihat pada kolom Corrected Item-Total Correlation) lebih besar dari $\mathrm{r}$ table dan nilai $\mathrm{r}$ positif, maka butir atau pernyataan tersebut dinyatakan valid. Hasil uji validitas dapat dilihat pada tabel. 1 berikut ini:

Tabel 1

Uji Validitas Instrumen

\begin{tabular}{|l|c|c|}
\hline \multirow{4}{*}{ Variabel } & Item & $\begin{array}{c}\text { Corrected Item-Total } \\
\text { Correlation }\end{array}$ \\
\hline Variabel Motivasi (X1) & $\mathrm{X} 11$ & 0.734 \\
\cline { 2 - 3 } & $\mathrm{X} 12$ & 0.824 \\
\cline { 2 - 3 } & $\mathrm{X} 13$ & 0.849 \\
\cline { 2 - 3 } & $\mathrm{X} 14$ & 0.785 \\
\hline Variabel Kepuasan Kerja (X2) & $\mathrm{X} 21$ & 0.656 \\
\cline { 2 - 3 } & $\mathrm{X} 22$ & 0.735 \\
\cline { 2 - 3 } & $\mathrm{X} 23$ & 0.771 \\
\cline { 2 - 3 } & $\mathrm{X} 24$ & 0.582 \\
\cline { 2 - 3 } & $\mathrm{X} 25$ & 0.820 \\
\cline { 2 - 3 } & $\mathrm{X} 26$ & 0.716 \\
\cline { 2 - 3 } & $\mathrm{X} 27$ & 0.856 \\
\cline { 2 - 3 } & $\mathrm{X} 28$ & 0.558 \\
\cline { 2 - 3 } & $\mathrm{X} 29$ & 0.691 \\
\hline Variabel Kinerja Karyawan & $\mathrm{Y} 11$ & 0.854 \\
\cline { 2 - 3 }$(\mathrm{Y})$ & $\mathrm{Y} 12$ & 0.874 \\
\cline { 2 - 3 } & $\mathrm{Y} 13$ & 0.868 \\
\cline { 2 - 3 } & $\mathrm{Y} 14$ & 0.721 \\
\cline { 2 - 3 } & $\mathrm{Y} 15$ & 0.789 \\
\hline r table & & 0.361 \\
\hline
\end{tabular}

Berdasarkan Tabel 1 di atas dapat ditunjukkan bahwa $r$ hitung > r tabel maka semua butir pernyataan (item) pada masing-masing variabel adalah valid. Sehingga data yang dihasilkan dapat dianalisis lebih lanjut.

\section{Hasil Uji Reliabilitas}


Pengujian reliabilitas berkaitan dengan masalah adanya kepercayaan terhadap alat test (instrument). Suatu instrument dapat memiliki tingkat kepercayaan yang tinggi jika hasil dari pengujian test instrument tersebut menunjukkan hasil yang tetap. Dengan demikian masalah reliabilitas test/ instrument berhubungan dengan ketepatan hasil. Hasil perhitungan koefisien korelasi dan reliabilitas untuk setiap variable penelitian dengan menggunakan metode Cronbach's Alpha disajikan pada table 2 di bawah ini.

Tabel 2

Uji Reliabilitas Instrumen

\begin{tabular}{|l|c|c|}
\hline \multicolumn{1}{|c|}{ Variabel } & Cronbach's Alpha & R tabel \\
\hline Variabel Motivasi (X1) & 0.801 & 0.361 \\
\hline Variabel Kepuasan Kerja (X2) & 0.874 & 0.361 \\
\hline Variabel Kinerja Karyawan (Y) & 0.875 & 0.361 \\
\hline
\end{tabular}

Jika nilai Cronbach's Alpha >r table (0.361) maka dapat dikatakan bahwa instrumen penelitian yang digunakan reliabel.

Berdasarkan tabel 2 di atas menunjukkan bahwa dari semua variable yang ada nilai CronbachAlpha'slebih besar dari pada nilai $r$ table (0.361). Sehingga dapat dikatakan bahwa semua item tersebut bersifat reliabel.

\section{Pengujian Asumsi Klasik}

Analisis regresi linear berganda yang digunakan untuk melakukan hipotesis. Sebelum digunakan untuk menguji hipotesis penelitian, terlebih dahulu model regresi yang diperolah dilakukan uji normalitas data dan uji asumsi klasik yang terdiri atas uji heteroskedastisitas dan uji multikolinearitas.

\section{Uji Normalitas}

Uji normalitas bertujuan untuk menguji apakah dalam model regresi, variabel pengganggu atau residual memiliki distribusi normal. Uji normalitas yang digunakan dalam penelitian ini adalah metode uji Kolmogorov-Smirnov, maka membacanya lihat Kolmogorov-Smirnov. Apabila nilai signifikansi > 0,05, maka lolos uji normalitas. Model regresi yang baik adalah yang memiliki distribusi secara normal. Cara nya adalah dengan normal probability plot yang membandingkan distribusi komulatif dari data sesungguhnya dengan distribusi komulatif dari distribusi normal. Data yang normal atau mendekati distribusi normal memiliki bentuk seperti lonceng. Hasil uji normalitas dengan menggunakan uji Nromalitas P-Plot dan grafik histogram digambarkan dalam gambar 1 dan gambar 2 berikut ini.

Gambar 1.

Uji Normalitas P-Plot

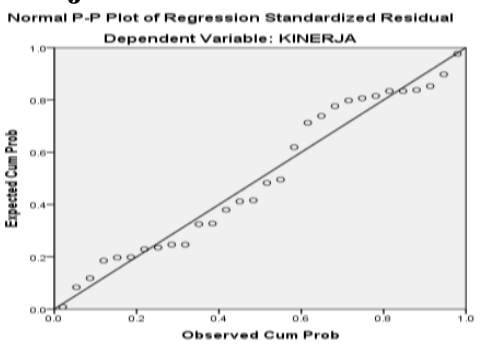

Sumber : Data Primer diolah SPSS 23, 2018 


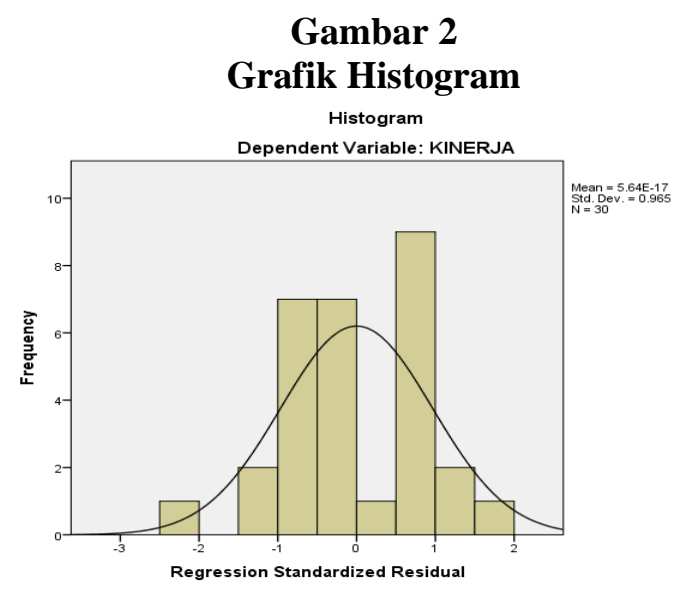

Sumber : Data Primer diolah SPSS 23, 2018

Dari gambar 1 dan gambar 2 di atas model regresi cenderung membentuk kurva normal yang cembung dengan angka standar deviasi mendekati satu yaitu sebesar 0.965.dan pada normal probability plot mengikuti garis diagonal. Dari hasil ini dapat disimpulkan bahwa model regresi berdistribusi normal.

\section{Uji Heteroskedastisitas}

Uji Heteroskedastisitas ini bertujuan untuk menguji apakah dalam model regresi terjadi ketidaksamaan varians dari residual satu pengamatan ke pengamatan lainnya. Jika varians dari satu pengamatan ke pengamatan yang lain tetap, maka disebut homoskedastisitas atau tidak terjadi heteroskedastisitas. Dan jika varians berbeda maka disebut heteroskedastisitas. Model regresi yang baik adalah yang homoskedastisitas atau tidak terjadi heteroskedastisitas. Deteksi ada tidaknya heteroskedastisitas dapat dilakukan dengan melihat ada tidaknya pola tertentu pada grafik scatterplot antara SRESID dan ZPRED dimana sumbu $\mathrm{Y}$ adalah $\mathrm{Y}$ yang diprediksi dan sumbu $\mathrm{X}$ adalah residual ( $\mathrm{Y}$ prediksi- $\mathrm{Y}$ sesungguhnya) yang telah di-standardized (Ghozali,2011). Hasil deteksi dengan scatterplot disajikan dalam gambar 3 di bawah ini.

\section{Gambar 3}

Uji Heteroskedastisitas

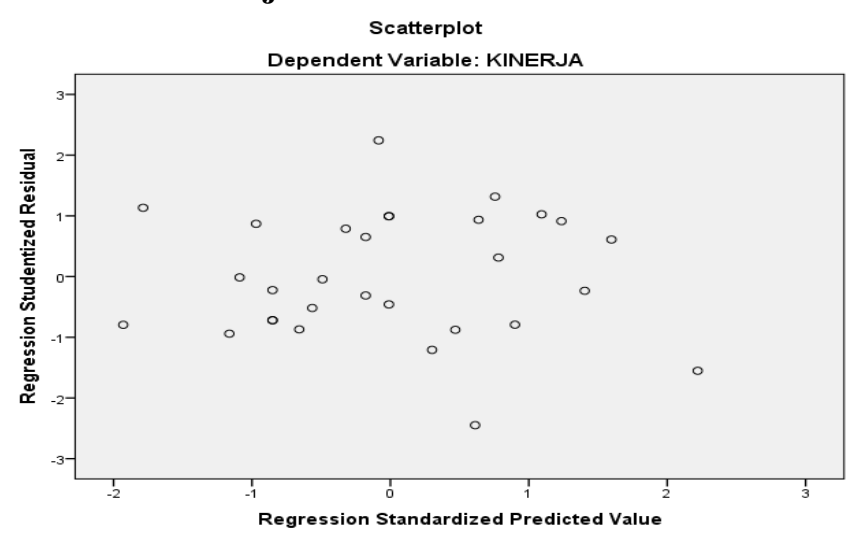

Berdasarkan Gambar 6 terlihat titik-titik menyebar secara acak baik di atas maupun di bawah angka 0 pada sumbu Y, dan juga terlihat titik-titik tersebut membentuk suatu pola 
tertentu. Dengan demikian dapat disimpulkan bahwa penelitian ini terbebas dari masalah heteroskedastisitas.

\section{Uji Multikolinearitas}

Uji Multikolinearitas bertujuan untuk menguji apakah model regresi ditentukan adanya korelasi diantara variable bebas. Pada program SPSS ada beberapa metode yang sering digunakan untuk mendeteksi adanya multikoloearitas. Salah satunya adalah dengan cara mengamati nilai Variance Inflation Factor (VIF) dan Tolerance. Batas VIF adalah 10 dan nilai dari Tolerance adalah 0.1. Jika nilai VIF lebih besar dari 10 dan nilai Tolerance kurang dari 0.1 maka terjadi multikolinearitas. Bila ada variabel independen yang terkena multikolinearitas, maka penanggulangannya adalah salah satu variable tersebut dikeluarkan(Ghozali, 2001: 74). Adapun hasil dari pengujian SPSS 23 untk mendeteksi terjadinya gejala multikolinearitas disajikan sebagai berikut.

\section{Tabel 3}

Hasil Uji Multikolinearitas Coefficients $^{\mathrm{a}}$

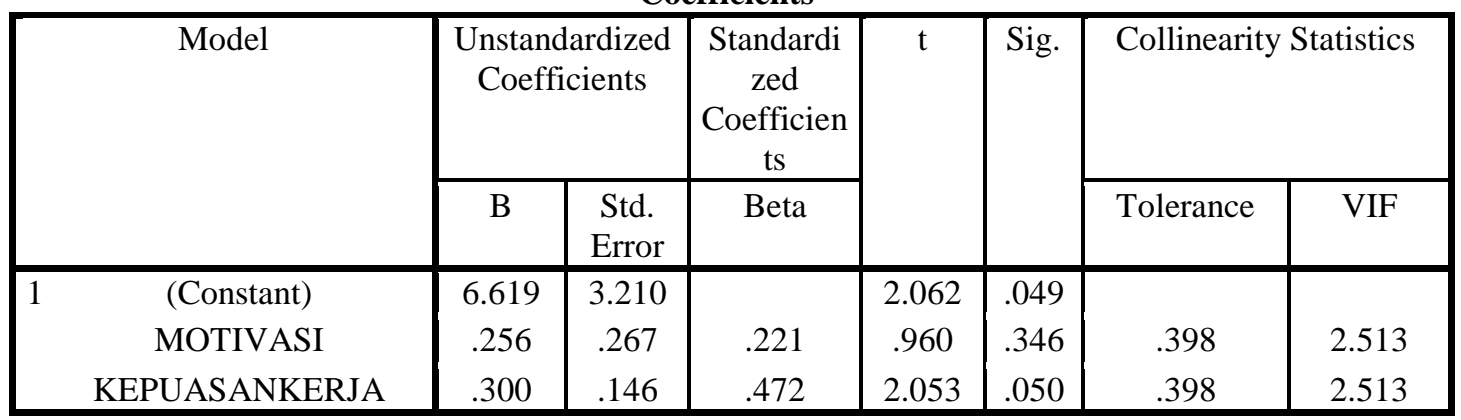

a. Dependent Variable: KINERJA

Berdasarkan hasil pengujian pada tabel 3 menunjukkan bahwa semua variabel yang digunakan dalam penelitian ini memiliki tolerance yang lebih dari 0.1 dan nilai VIF yang kurang dari 10. Hal ini berarti bahwa variabel-variabel penelitian tidak menunjukkan adanya gejala multikolinearitas dalam model regresi.

Pengujian-pengujian di atas telah membuktikan kalau data yang akan digunakan telah memenuhi syarat normalitas, tidak ada heteroskedastisitas dan bebas multikolinearitas. Dengan 3 pengujianpendahuluan ini makapengujian atas multiple regression dapat dilakukan dengan hasil yang akurat.

\section{Hasil Uji Linier Berganda}

Hasil pengujian regresi berganda untuk mengetahui pengaruh dari motivasi dan kepuasan kerja terhadap kinerja pegawai BPS Kabupaten Ogan Ilir menggunaka SPSS 23. Hasil uji regresi linier berganda dapat dilihat pada tabel 4 di bawah ini.

Tabel 4

Hasil Analisis Regresi

\begin{tabular}{|c|c|c|c|c|c|c|}
\hline \multirow{2}{*}{\multicolumn{2}{|c|}{ Model }} & \multicolumn{2}{|c|}{ Unstandardized Coefficients } & $\begin{array}{c}\text { Standardized } \\
\text { Coefficients }\end{array}$ & \multirow[b]{2}{*}{$\mathrm{t}$} & \multirow[b]{2}{*}{ Sig. } \\
\hline & & B & Std. Error & Beta & & \\
\hline 1 & $\begin{array}{c}\text { (Constant) } \\
\text { MOTIVASI } \\
\text { KEPUASANKERJA }\end{array}$ & $\begin{array}{l}6.619 \\
.256 \\
.300\end{array}$ & $\begin{array}{l}3.210 \\
.267 \\
.146\end{array}$ & $\begin{array}{l}.221 \\
.472\end{array}$ & $\begin{array}{c}2.062 \\
.960 \\
2.053\end{array}$ & $\begin{array}{l}.049 \\
.346 \\
.050\end{array}$ \\
\hline
\end{tabular}

a. Dependent Variable: KINERJA 
$\mathrm{Y}=\mathrm{a}+\mathrm{b} 1 \mathrm{X} 1+\mathrm{b} 2 \mathrm{X} 2+\mathrm{e}$

$\mathrm{Y}=6.619+0,256 \mathrm{X} 1+0,3 \mathrm{X} 2+\mathrm{e}$

Berdasarkan hasil uji analisis regresi pada tabel 4 diatas menunjukkan bahwa hanya 1 variabel kepuasan kerja yang berpengaruh terhadap kinerja pegawai karena nilai $\mathrm{T}$ hitung $>\mathrm{T}$ table (2.042).

Berdasarkan persamaan garis regresi dugaan tersebut, maka:

- Koefisien konstanta sebesar 6.619 artinya jika tidak ada motivasi dan kepuasan kerja maka kinerja pegawai BPS Ogan ilir hanya sebesar 6.619 atau $661.9 \%$.

- Jika terjadi peningkatan dalam motivasi sebesar $1 \%$ sementara variable bebas lainnya tetap, maka kinerja pegawai akan meningkat sebesar $25.6 \%$ begitu pula sebaliknya.

- Jika terjadi peningkatan dalam kepuasan kerja sebesar $1 \%$ sementara variable bebas lainnya tetap, maka kinerja pegawai akan meningkat sebesar $30 \%$ begitu pula sebaliknya

\section{Hasil Uji t (Uji Parsial)}

Untuk menerima atau menolak, harus terlebih dahulu ditentukan aturan main (Decision Table). Dengan adanya ketentuan ini, maka akan diketahui nilai kritis untuk pedoman menerima atau menolak hipotesis. Pengambilan keputusan untuk menolak atau menerima hipotesis didasarkan pada:

$\mathrm{H} 0: \mathrm{b}_{\mathrm{i}}=0 \quad$ (Motivasi dan Kepuasan Kerja tidak berpengaruh signifikan dan positif secara parsial terhadap kinerja pegawai BPS Kabupaten Ogan Ilir).

$\mathrm{H} 1: \mathrm{b}_{\mathrm{i}}=0 \quad$ (Motivasi dan Kepuasan Kerja berpengaruh signifikan dan positif secara parsial terhadap kinerja pegawai BPS Kabupaten Ogan Ilir).

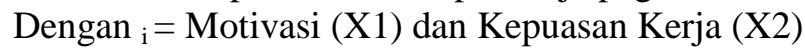

Dengan ketentuan jika hasil t hitung $>\mathrm{t}$ table maka keputusannya adalah Ho ditolak dan $\mathrm{H} 1$ diterima. Sebaliknya jika hasil $\mathrm{t}$ hitung $<\mathrm{t}$ table maka keputusannya adalah Ho diterima dan $\mathrm{H} 1$ ditolak. Berikut ini adalah tabel koefisien regresi yang digunakan sebagai dasar uji parsial.

Tabel 5

Koefisien Regresi

\begin{tabular}{|cc|c|c|c|c|c|}
\hline \multirow{2}{*}{} & & \multicolumn{2}{|c|}{$\begin{array}{c}\text { Unstandardized } \\
\text { Coefficients }\end{array}$} & $\begin{array}{c}\text { Standardized } \\
\text { Coefficients }\end{array}$ & & \\
\cline { 2 - 5 } & Model & $\mathrm{B}$ & Std. Error & Beta & $\mathrm{t}$ & Sig. \\
\hline 1 & (Constant) & 6.619 & 3.210 & & 2.062 & .049 \\
& MOTIVASI & .256 & .267 & .221 & .960 & .346 \\
& KEPUASANKERJA & .300 & .146 & .472 & 2.053 & .050 \\
\hline
\end{tabular}

a. Dependent Variable: KINERJA

1) Uji t (Uji Parsial) untuk Variabel Motivasi (X1)

Berdasarkan tabel 5 dapat diketahui bahwa variabel motivasi kurang berpengaruh signifikan terhadap kinerja, dimana $t$ hitung < dari pada t table $(0.960<2.042)$ dengan sig sebesar 0.346 yang lebih besar dari 0.05. Dengan demikian Ho diterima dan H1 ditolak.

2) Uji t (Uji Parsial) untuk Variabel Kepuasan Kerja

Berdasarkan tabel 7 dapat diketahui bahwa variabel Kepuasan Kerja berpengaruh signifikan terhadap kinerja, dimana $t$ hitung $>$ dari pada $t$ table $(2.053<2.042)$ dengan sig sebesar 0.05. Dengan demikian Ho ditolak H1 diterima. 


\section{Hasil Uji F (Uji Simultan)}

Korelasi menjelaskan hubungan antara variabel bebas $\left(\mathrm{X}_{1}-\mathrm{X}_{2}\right)$ yang tersusun dalam model persamaan regresi yang terdiri dari motivasi dan kepuasan kerja berpengaruh positif dan signifikan terhadap kinerja pegawai BPS Kabupaten Ogan Ilir (Y).

Hipotesis dalam penelitian ini adalah sebagai berikut:

$\mathrm{H} 0: \mathrm{b}_{1}, \mathrm{~b}_{2}, \mathrm{~b}_{3}=0$ (Motivasi dan kepuasan kerja tidak berpengaruh signifikan terhadap kinerja pegawai BPS Kabupaten Ogan Ilir)

$\mathrm{H} 1: \mathrm{b} 1, \mathrm{~b} 2, \mathrm{~b} 3 \neq 0 \quad$ (Motivasi dan kepuasan kerja berpengaruh signifikan terhadap kinerja pegawai BPS Kabupaten Ogan Ilir)

Pengujian hipotesis secara keseluruhan (simultan) dilakukan dengan uji statistik Uji $\mathrm{F}$ melalui ANOVA (Analysis Of Variance). Dengan ketentuan jika hasil $\mathrm{F}$ hitung $>\mathrm{F}$ table maka keputusannya $\mathrm{H} 0$ ditolak dan $\mathrm{H} 1$ diterima. Sebaliknya jika hasil $\mathrm{F}$ hitung < F table maka keputusannya H0 tidak ditolak (diterima) dan H1 tidak diterima (ditolak). berikut ini.

Adapun tabel di bawah ini akan menyajikan hasil uji ANOVA seperti dalam tabel 6

\section{Tabel 6}

Hasil Uji F ANOVA ${ }^{\text {a }}$

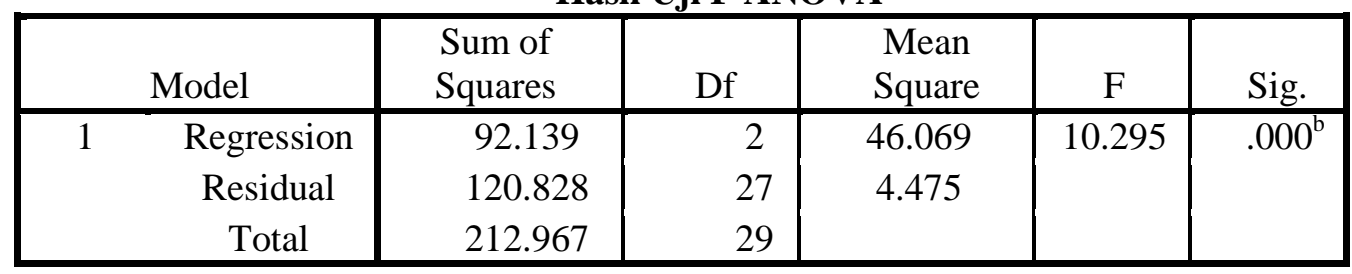

a. Dependent Variable: KINERJA

b. Predictors: (Constant), KEPUASANKERJA, MOTIVASI

Sumber : Data diolah SPSS 23, 2018

Dari hasil uji Anova atau F test didapat F hitung sebesar 10.295 dengan tingkat signifikansi 0.000 lebih besar dari pada $\mathrm{F}$ tabel sebesar 3.34 ( $\mathrm{F}$ hitung $>\mathrm{F}$ tabel) sehingga dapat dikatakan bahwa variabel motivasi dan kepuasan kerja secara simultan pengaruh signifikan terhadap kinerja pegawai BPS Kabupaten Ogan Ilir. Maka dapat disimpulkan bahwa terdapat pengaruh yang sifnifikan antara variabel X1 X2 (Motivasi dan Kepuasan Kerja) terhadap Variabel Y (Kinerja) dengan demikian Ho ditolak dan H1 diterima.

\section{Koefisien Determinasi $\left(\mathbf{R}^{2}\right)$}

Koefisien determinasi menjelaskan seberapa besar kontribusi yang diberikan oleh variabel bebas terhadap variabel kinerja pegawai Badan Pusat Statistik Kabupaten Ogan Ilir. Berikut ini disajikan output model summary SPSS 23 pada tabel

7 berikut ini :

\section{Tabel 7}

Model Summary ${ }^{\mathrm{b}}$

\begin{tabular}{|c|c|c|c|c|}
\hline Model & R & R Square & $\begin{array}{c}\text { Adjusted R } \\
\text { Square }\end{array}$ & $\begin{array}{c}\text { Std. Error of } \\
\text { the Estimate }\end{array}$ \\
\hline 1 & $.658^{\mathrm{a}}$ & .433 & .391 & 2.115 \\
\hline
\end{tabular}

a. Predictors: (Constant), KEPUASANKERJA, MOTIVASI

b. Dependent Variable: KINERJA

Sumber : Data Primer diolah SPSS 23, 2018 
Berdasarkan tabel 7 di atas, koefisien R sebesar 0.658 berarti variabel bebas memiliki hubungan yang erat dengan kinerja pegawai Badan Pusat Statistik Kabupaten Ogan Ilir. Sedangkan R2 (koefisien determinasi) adalah sebesar 0.433 atau 43.3\%. Ini berarti, kedua variabel bebas $(\mathrm{X} 1, \mathrm{X} 2)$ dapat menjelaskan kinerja pegawai Badan Pusat Statistik Kabupaten Ogan Ilir dengan kontribusi sebesar 43.3\% sedangkan sisanya 56.7\% (100\% - 43.3\%) dipengaruhi oleh faktor lain yang tidak diteliti dalam penelitian ini.

Diantara indikator-indikator penentu kinerja, motivasi dan kepuasan kerja dipandang sebagai prediktor penting. Kesuksesan suatu organisasi dalam mencapai tujuan dan sasaran tergantung pada motivasi dan kepuasan kerja.

Dalam penelitian ini, berdasarkan hasil pengujian empiris didapatkan bahwa variabel motivasi tidak berpengaruh signifikan terhadap kinerja pegawai BPS Kabupaten Ogan Ilir pada taraf nyata 5\%. Dengan kata lain secara lokasi jika dilihat dari indikatornya yakni : kesempatan mengembangkan kreativitas, pengerahan kemapuan, pengembangan diri dan kesempatan memperoleh kekuasaan atau kedudukan dalam organisasi tidak mempengaruhi kinerja karyawan BPS kabupaten Ogan Ilir. Ini akan menjadi tantangan bagi organisasi untuk meningkatkan motivasi kerja. Hal ini dikarenakan indikator seperti yang telah disebutkan di atas belum dijalankan secara optimal oleh manajemen BPS Kabupaten Ogan Ilir.Tiga kelompok kebutuhan manusia yang dapat memotivasi gairah kerja adalah: 1. Kebutuhan akan afiliasi, 2. Kebutuhan prestasi dan 3. Kebutuhanakan kekuasaan. Dengan kata lain kebutuhan dasar dari pegawai Badan Pusat Statistik Kabupaten Ogan Ilir, artinya jaminan kesehatan, jaminan pendidikan keluarga, fasilitas kantor insentif/ tunjangan dan lain sebagainya telah memadai. Disamping itu terdapat kegiatan-kegiatan pengembangan pegawai seperti pelatihan, diklat, seminar dan sebagainya. Akan tetapi pegawai yang dikirim oleh Badan Pusat Statistik Kabupaten Ogan Ilir yang itu-itu saja, artinya belum terjadi prinsip keadilan secara distributive. Ditambah lagi dengan adanya mutasi pegawai dari kantor BPS kabupaten/ kota lainnya yang ditempatkan dengan kompetensi yang tentu saja dinilai baik. Hal ini menyebabkan pegawai lebih pada melaksanakan rutinitas pekerjaan sehari-hari saja sehingga belum terdapat kreativitas dan inovasi dalam pekerjaan yang dapat menunjang kinerja pegawai itu sendiri.

Dari hasil penelitian didapatkan Motivasi yang dilakukan oleh pimpinan tidak berpengaruh signifikan terhadap kinerja pegawai, disebabkan oleh adanya pegawai yang tidak mau berkreatifitas di dalam bekerja sehingga mereka melaksanakan tugas berdasarkan perintah. Jadi hipotesa dalam penelitian ini yang menyatakan bahwa motivasi mempunyai pengaruh signifikan terhadap kinerja pegawai pada Badan Pusat Statistik Kabupaten Ogan Ilir, ditolak.

Faktor lainnya yang menunjang bagi individu dalam mencapai kinerja pegawai BPS Ogan Ilir adalah kepuasan kerja. Berdasarkan hasil pengujian empiris yang didapatkan bahwa variable kepuasan kerja berpengaruh terhadap kinerja pegawai BPS Kabupaten Ogan Ilir pada taraf nyata 5\%. Dengan kata lain kepuasan kerja jika dilihat dari indikatornya yakni : pekerjaan, pengawasan, gaji, promosi, kondisi kerja dan sistem penilaian ternyata cukup mempengaruhi kinerja pegawai BPS Kabupaten Ogan Ilir dengan koefisien regresi sebesar 0.3 dan nilai signifikansi 0.05 (sama dengan taraf nyata yang digunakan). Dilihat dari sisi pegawai tetap hal ini sesuai dengan kondisi yang ada di Badan Pusat Statistik Kabupaten Ogan Ilir yang memang secara pekerjaan itu sendiri, gaji, kesempatan promosi, supervisor dan rekan kerja memang telah diterapkan sesuai dengan ketentuan yang berlaku. Namun bagi pegawai honorer di lingkungan Badan Pusat Statistik Kabupaten Ogan Ilir masih merasa kurang puas dengan kompensasi yang diberikan, sehingga terdapat perbedaan yang terlalu mencolok antara pegawai tetap dan honorer. Jika kepuasan kerja rendah maka kinerja 
pegawai di lingkungan Badan Pusat Statistik juga akan rendah dan sebaliknya. Jadi hipotesa dalam penelitian ini yang menyatakan bahwa kepuasan kerja mempunyai pengaruh signifikan terhadap pegawai BPS Kabupaten Ogan Ilir, dapat diterima.

\section{SIMPULAN DAN SARAN}

\section{Simpulan}

1. Variabel motivasi tidak berpengaruh signifikan secara parsial terhadap kinerja pegawai Badan Pusat Statistik Kabupaten Ogan Ilir, disebabkan masih adanya pegawai yang tidak mau berkreatifitas di dalam bekerja dan tugas yang dilaksanakan hanya berdasarkan apa yang diperintahkan.

2. Variabel kepuasan kerja berpengaruh signifikan secara parsial terhadap kinerja pegawai Badan Pusat Statistik Kabupaten Ogan Ilir, terutama bagi pegawai tetap dimana jika kepuasan kerja tinggi maka kinerja pegawai juga akan tinggi dan sebaliknya.

3. Hipotesis ketiga penelitian ini yang menyatakan bahwa motivasi dan kepuasan kerja berpengaruh signifikan secara bersama-sama terhadap kinerja pegawai Badan Pusat Statistik Kabupaten Ogan Ilir, diterima. Pengaruh signifikan dibuktikan dari nilai F hitung sebesar 10.295 dengan nilai $\mathrm{R}$ square sebesar 0.433 (43.3\%) dengan persamaan regresi berganda sebagai berikut: $\mathrm{Y}=6.619+0,256 \mathrm{x} 1+0,3 \mathrm{X} 2+\mathrm{e}$

4. Sedangkan variabel yang dominan mempengaruhi kinerja pegawai Badan Pusat Statistik Kabupaten Ogan Ilir adalah variabel kepuasan kerja dengan nilai signifikansi ( $\mathrm{p}=0.05$ dan $b=0.3$ ). Jika kepuasan kerja pegawai tinggi maka kinerja organisasi juga akan baik dan sebaliknya.

\section{Saran}

1. Pimpinan dan kepala seksi di lingkungan Badan Pusat Statistik Kabupaten Ogan Ilir hendaknya meningkatkan pengawasan untuk memberikan kesempatan serta mendorong pegawai mengembangkan kreativitas, pengerahan kemampuan dan mengembangkan diri dalam menjalankan tugas. Dan juga memberikan kesempatan memperoleh kekuasaan dalam organisasi secara adil dan menyeluruh terhadap pegawainya sehingga pegawai dapat termotivasi dan dapat memberikan hasil kerja yang lebih optimal lagi.

2. Dari hasil penelitian yang telah dilakukan, variabel kepuasan kerja merupakan variabel yang paling dominan dalam mempengaruhi kinerja. Oleh karena itu dukungan lebih dari supervisor (kepala seksi) dan pimpina agar dapat memberikan pengertian kepada pegawai honorer akan perbedaan kompensasi sehingga semua pegawai dapat lebih memaksimalkan kemampuannya dalam melakukan pekerjaannya.

3. Penelitian di lingkungan Badan Pusat Statistik Kabupaten Ogan Ilir ini dapat dikembangkan dengan melihat faktor-faktor lain yang dapat mempengaruhi peningkatan kinerja pegawai seperti: kompetensi kerja, kualitas pengawasan, persepsi atas karakteristik tugas, keterlibatan kerja/ partisipasi, beban kerja, minat, kondisi fisik dari lingkungan kerja dan lain sebagainya.

\section{DAFTAR PUSTAKA}

Arikunto, S. 1998. Prosedur Penelitian Suatu Pendekatan Praktek. Jakarta. PT Rineka Cipta. 2002. Prosedur Penelitian Suatu Pendekatan Praktek. Jakarta. PT Rineka Cipta. 
Arikunto, S \& Suharjono \& Supardi. 2006. Penelitian Tindakan Kelas . Jakarta. PT. Bumi Aksara.

Luthans, F. 2011. Organixational Behavior: An Evidence- Based Approach. Bandung. PT Trigenda Karya.

Hasibuan, Malayu S.P. 2000. Manajemen Sumber Daya Manusia. Edisi Revisi. Jakarta. PT Bumi Aksara 2001. Manajemen Sumber Daya Manusia. Jakarta. PT Bumi Aksara 2006. Manajemen Dasar, Pengertian dan Masalah. Edisi Revisi. Jakarta. PT Bumi Aksara 2007. Manajemen Sumber Daya Manusia. Cetakan 9. Jakarta. PT Bumi Aksara

Malthis, R.L \& J.H. Jackson. 2006. Human Resource Management: Manajemen Sumber Daya Manusia. Terjemahan Dian Angelia. Jakarta. Salemba Empat

Mangkunegara, A.P. 2000. Manajemen Sumber Daya Manusia. Bandung. Remaja Rosdakarya

Robbins, S.P. 2001. Manajemen Motivasi. Bandung. CV Alfabeta

Siagian, 2001. Manajemen Sumber Daya Manusia. Jakarta. PT Bumi Aksara.

Sugiyono. 2003. Metode Penelitian Bisnis. Edisi 4, Bandung. Cv. Alfabeta 2008. Meetode Penelitian Kuantitatif Kualitatif dan R \& D. Bandung. CV Alfabeta 2011. Metode Penelitian Kuantitatif Kualitatif dan R \& D. Bandung. CV Alfabeta

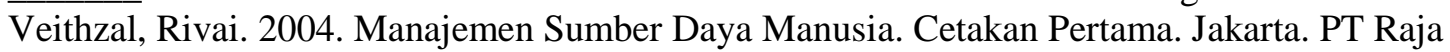
Grafindo Persada 